\title{
Disolusi Kapsul Dispersi Padat Piroksikam-PEG 6000 Selama Penyimpanan
}

\author{
Annas Binarjo, Husnul Khotimah \\ Fakultas Farmasi Universitas Ahmad Dahlan Yogyakarta \\ Email : annasbinarjo@yahoo.co.id
}

\begin{abstract}
Abstrak
Kelarutan piroksikam yang rendah mempengaruhi laju disolusi sebagai penentu bioavaibilitas. Pembuatan dispersi padat dengan piroksikam-polietilenglikol dapan meningkatkan laju disolusinya. Tujuan penelitian ini adalah untuk mengetahui pengaruh pembentukan dispersi padat piroksikampolietilenglikol 6000 (PEG 6000) terhadap laju disolusi kapsul piroksikam selama 1 bulan penyimpanan. Rekristal piroksikam (R) dan dispersi padat piroksikam-PEG 6000 (DP) dibuat dengan metode pelarut menggunakan campuan aseton-etanol (1:1), keduanya bersama dengan piroksikam tanpa modifikasi $(\mathrm{P})$ dikapsul dan disimpan selama 1 bulan. Uji disolusi dilakukan setiap minggu. Efisiensi disolusi 60 menit (DE60), prosentase disolusi 45 menit (C45), dan waktu untuk 80\% terdisolusi (t80) digunakan sebagai parameter disolusi. Kurva hubungan DE60, C45, dan 180 terhadap waktu penyimpanan dilihat slopenya sebagai parameter stabilitas. Hasil percobaan menunjukkan bahwa Kapsul P dan DP menunjukkan nilai DE60, C45, dan 180 yang stabil selama penyimpanan (slope $=0, \mathrm{p}>0.05$ ), demikian juga nilai t80 kapsul R. Sedangkan DE60 dan C45 kapsul R selama penyimpanan terus menurun dengan slope $-0,636 \% /$ hari dan $-0,171 \mathrm{mg} / \mathrm{hari}$. Dapat disimpulkan bahwa DP yang dibuat dengan metode pelarut campuran aseton dan etanol $(1: 1)$ menunjukkan profil disolusi yang stabil selama penyimpanan 1 bulan..
\end{abstract}

Kata kunci : disolusi, piroksikam, dispersi padat, polietilenglikol 6000, stabilitas

\section{Dissolution Of Solid Dispersion Piroxicam-PEG 6000 Capsules During Storage}

\begin{abstract}
The low solubility of piroxicam affect its rate of dissolution as bioavailability limiting factor. Solid dispersion using polyethilenglycol can improve its dissolution rate. This research was aimed to determine the effect of piroxicam-polyethylenglycol 6000 (PEG 6000) solid dispersion formation on the dissolution rate of piroxicam capsules during storage for 1 month. The piroxicam recrystal (R) and solid dispersion of piroxicam-PEG 6000 (DP) were prepared by solvent method using acetone-ethanol (1:1), these two bulk and unmodified piroxicam (P) as control than be capsulated and stored for 4 . Their dissolution were tested every week. Sixty minutes dissolution efficiency (DE60), percent drug dissolved in 45 minutes (C45), and time to dissolve $80 \%$ of drug (t80) were used as dissolution parameters. The slope of the plot of these dissolution parameters as a function of time storage was used as a stability indicator. The result show that P and DP capsules have a constant DE60, C45, and t80 during storage (slope $=0, p>0.05$ ), also the data of $t 80$ of $\mathrm{R}$ capsule. DE60 and C45 of R capsule is going lower during the storage with the slope of $-0,636 \% /$ day and $-0,171 \mathrm{mg} / \mathrm{day}$. It can be concluded that DP prepared by solvent method using acetoneethanol (1:1) shows the stable dissolution profiles during storage for 1 month.
\end{abstract}

Keywords: dissolution, piroxicam, solid dispersion, polyethylenglycol 6000, stability 


\section{Pendahuluan}

Piroksikam mempunyai kelarutan yang rendah. ${ }^{1,2}$ Obat dengan kelarutan yang rendah mempunyai masalah dalam proses disolusinya, ${ }^{3}$ oleh karena itu diperlukan upaya untuk memperbaiki kelarutannya. Beberapa upaya yang sudah dilakukan adalah pembentukan dispersi padat obat yang sukar larut dengan pembawa yang mudah larut, ${ }^{4}$ mikronisasi, ${ }^{5}$ pembentukan kompleks, ${ }^{6}$ dan rekristalisai. ${ }^{2}$ Pada proses rekristalisasi dan pembentukan dispersi padat ada peluang terjadinya perubahan bentuk kristal. Bentuk kristal berpengaruh terhadap disolusi dan bioavailabilitas. ${ }^{7}$

Untuk piroksikam, pembentukan dispersi padat dalam rangka memperbaiki disolusi sudah dilakukan dengan beberapa pembawa. misalnya siklodekstrin. Penerapan metode pelarut lebih baik dalam mempercepat disolusi daripada metode pelehan. Pada metode pelarut, lebih dari $65 \%$ piroksicam berada dalam bentuk amorf. ${ }^{8}$ Pembentukan padatan amorf yang memiliki kelarutan yang jauh lebih baik juga didapatkan pada pembentukan dispersi padat dengan pembawa Mirj 52, Eudragit, dan manitol. ${ }^{9}$ Beberapa polimer yaitu PEG 4000, PEG 6000, PVP K30, dan PVP K90 digunakan sebagai pembawa dispersi padat piroksikam yang dibuat dengan metode pelarut. PEG 6000 mempunyai kemampuan peningkatan disolusi yang paling baik dibandingkan polimer yang lain. ${ }^{10}$ Beberapa pendekatan dilakukan untuk mengetahui efisiensi pembentukan dispersi padat, antara lain pengujian kelarutan, ${ }^{9}$ uji disolusi, ${ }^{10}$ penentuan kecepatan disolusi intrinsik, ${ }^{11}$ dan pengujian bioavailabilitas pada hewan uji. ${ }^{12}$ Analisis instrumental dengan spektrofotometri infra merah dan difraksi sinar-x juga dilakukan untuk melihat perubahan bentuk kristal.9 Selain peningkatan disolusi, pembentukan disperssi padat juga berguna untuk meurunkan efek samping obat, misalnya pembentukan dispersi padat meloksikam dengan PEG 6000 dan komponen dari susu skim yang dapat menurunkan efek samping gangguan lambung. Peningkatan disolusi meloksikam pada sediaan dengan dispersi padat mencegah kontak kristal meloksikam dengan dinding lambung, karena segera melarut setelah sediaan hancur. ${ }^{13,14}$

Dalam semua penelitian di atas, pengujian hasil rekristalisasi maupun disperse padat dilakukan satu kali, yaitu segera setelah diperoleh padatan. Bentuk kristal suatu padatan akan berubah seiring dengan berjalannya waktu, sampai mencapai kondisi bentuk kristal yang paling stabil. Artinya kristal yang mempunyai karakter disolusi yang bagus ketika baru saja terbentuk, dapat berubah menjadi kristal bentuk lain yang mempunyai karakter disolusi yang jelek kembali setelah disimpan. ${ }^{15}$

Uji stabilitas penyimpanan merupakan bagian penting program uji bahan obat karena ketidakstabilan produk ditentukan oleh tiga syarat utama yaitu kualitas, efikasi, dan keamanan. Selama penyimpanan sediaan dapat terjadi perubahan- perubahan karakteristik fisikokimia. Hal tersebut dapat mempengaruhi laju disolusi obat.16 Penelitian ini bertujuan untuk mengetahui stabilitas disolusi kapsul piroksikam yang telah dimodifikasi dengan rekristalisasi dan pembentukan dispersi padat dengan pembawa PEG 6000. Pembawa PEG 6000 paling banyak dipakai sebagai pembawa dispersi padat dan terbukti memberikan tingkat peningkatan kecepatan disolusi piroksikam yang lebih tinggi dibandingkan polimer yang lain. ${ }^{10,17}$

\section{Metode Penelitian}

\section{Bahan dan Alat}

Bahan utama dari penelitian ini adalah piroksikam pharmaceutical grade yang diperoleh dari PT IFARS Pharmaceutical Laboratories Surakarta. Untuk Uji disolusi digunakan Dissolution Tester Tipe dayung pabrikan ERWEKA. Penentuan kadar obat hasil disolusi dilakukan dengan menggunkan Spektrofotometer Shimadzu 1700. 


\section{Cara Kerja}

Pembuatan Rekristal Piroksikam dan

Dispersi Padat Piroksikam-PEG

Rekristalisasipiroksikamdanpembuatan dispersi padat piroksikam dilakukan dengan metode pelarut. ${ }^{18}$ Piroksikam atau campuran fisik piroksikam-PEG 6000 1:1 dilarutkan dalam pelarut campur etanol dan aseton 1:1 hingga tepat larut. Kemudian solven diuapkan dalam lemari asam sampai diperoleh bobot yang tetap.

\section{Uji Stabilitas}

Setiap formula dikemas ke dalam kapsul, 1 kapsul berisi piroksikam $20 \mathrm{mg}$ atau dispersi padat yang setara dengan $20 \mathrm{mg}$ piroksikam (20 mg adalah dosis terbesar untuk sediaan padat piroksikam) dan laktosa sebagai pengisi. Kapsul dimasukkan ke dalam botol yang dibalut dengan aluminium foil sebanyak 8 botol untuk 4 kali sampling masing-masing hari ke-0, 7, 14,21 dan hari ke 28 dengan masing-masing dilakukan 4 kali replikasi. Setelah sampai waktu sampling, diambil satu kapsul untuk diuji disolusi.

\section{Pembuatan Kurva Baku Piroksikam}

Kurva baku dibuat dengan cara mengencerkan larutan induk $1 \mathrm{mg} / \mathrm{ml}$ piroksikam menggunakan dapar $\mathrm{HCl} \mathrm{pH}$ 1,2, hingga diperoleh konsentrasi $0,1 \mathrm{mg} /$ ml, kemudian dari $0,1 \mathrm{mg} / \mathrm{ml}$ diencerkan hingga diperoleh beberapa konsentrasi larutan baku yaitu seri kadar $0,3 \mathrm{mg} / 100 \mathrm{ml}$, $0,5 \mathrm{mg} / 100 \mathrm{ml}, \quad 0,7 \mathrm{mg} / 100 \mathrm{ml}, \quad 0,9$ $\mathrm{mg} / 100 \mathrm{ml}, 1,1 \mathrm{mg} / 100 \mathrm{ml}, 1,3 \mathrm{mg} / 100 \mathrm{ml}$.
Absorbansi larutan baku dibaca pada panjang gelombang maksimum. Kurva baku dispersi padat dibuat perlakuan sama namun larutan induk dibuat piroksikam PEG 6000 (1:1).

\section{Uji Disolusi}

Kondisi uji disolusi mengacu pada monograf USP, ${ }^{19}$ dengan sedikit modifikasi pada medium, yaitu medium simulated gastric fluid yang mengandung $\mathrm{HCl}$ dan $\mathrm{NaCl}$ dengan $\mathrm{pH}$ 1,2 diganti dengan $\mathrm{HCl}$ saja dengan $\mathrm{pH} 1,2$. Limaratus $\mathrm{ml}$ dapar $\mathrm{HCl} \mathrm{pH}$ 1,2 sebagai media dimasukkan ke dalam alat uji disolusi USP tipe 2, temperatur media dibuat konstan $37^{\circ} \pm$ $0.5^{\circ} \mathrm{C}$. Satu kapsul dimasukkan ke dalam tabung disolusi, dihilangkan gelembung udara dari permukaan sediaan yang diuji dengan segera alat dijalankan pada laju kecepatan 100 rotasi per menit selama 60 menit. Sampling diambil pada menit ke 5,15,30,45, dan 60, sebanyak 5,0 ml, dan langsung diukur absorbansinya pada panjang gelombang maksimum. Setiap pengambilan sampel cairan medium diganti dengan medium yang baru dengan volume dan suhu yang sama.

\section{Analisis Data}

Pembuatan Kurva Baku Piroksikam

Persamaan kurva baku piroksikam dibuat melalui hubungan antara konsentrasi piroksikam sebagai fungsi absorbansinya. Persamaan kurva baku ini selanjutnya digunakan untuk menentukan konsentrasi sampel hasil percobaan kelarutan.

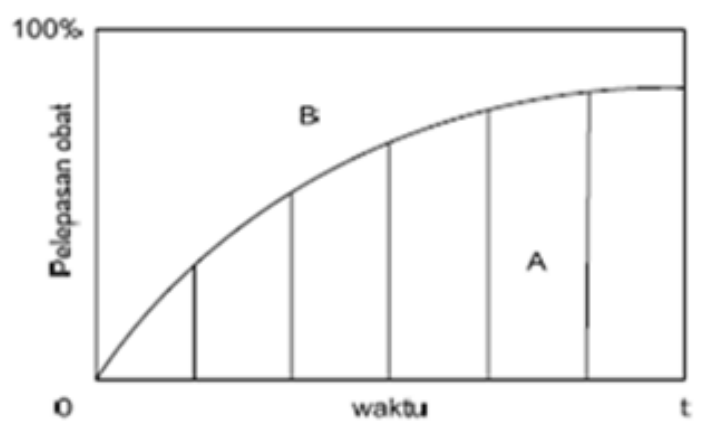

Gambar 1 Kurva Disolusi 
Uji disolusi

Kurva jumlah obat terdisolusi versus waktu (Gambar 1) digunakan untuk menghitung parameter disolusi yaitu DE60 dengan persamaan 1.20

$$
\begin{gathered}
\text { Luas daerah A } \\
\text { LE60 = ----------- x 100\% }
\end{gathered}
$$

Lama uji disolusi adalah 1 jam. Luas daerah A dihitung dengan menjumlahkan luas setiap potongan trapezium, sedangkan luas daerah $(\mathrm{A}+\mathrm{B})$ adalah $100 \%$ dikalikan 60 menit.

Nilai C45 dan t80 dihitung dengan menggunakan persamaan Wagner, yang tunjukkan dalam persamaan 2.21

$$
\ln 100(\mathrm{~W} 0-\mathrm{W})=\mathrm{A}-\mathrm{kt}
$$

Keterangan :

W0 = bobot zat padat tertinggi yang dapat larut

$\mathrm{W}=$ bobot zat padat yang terlarut pada waktu $\mathrm{t}$

A = tetapan yang mengandung faktorfaktor kelarutan, luas spesifik dan tetapan kecepatan pelarutan pada awal proses ( $\mathrm{t} 0$ )

$\mathrm{k}=$ tetapan kecepatan pelarutan

$\mathrm{t} \quad=$ waktu

Analisis Stabilitas

Data DE60, C45 dan t80 di-plotkan terhadap waktu penyimpanan. Nilai slope yang negatif pada plot DE60 dan C45 terhadap waktu penyimpanan dan slope positif pada t80 menunjukkan ketidakstabilan disolusi. Nilai slope dari 4 replikasi dibandingkan dengan 0 dengan One Sample T-test (SPSS 16 for Windows). Jika hasil One Sample T-test dengan test value 0 menunjukkan signifikansi $p>0.05$ maka slope tidak berbeda bermakna dengan 0 (tidak ada slope) yang artinya parameter disolusi tersebut stabil.

\section{Hasil}

Hasil Pembuatan Rekristalisasi Piroksikam dan Dispersi Padat Piroksikam-PEG 6000 $(1: 1)$

Pada percobaan ini rekristalisasi dilakukan dengan menggunakan metode pelarut. Pelarut yang digunakan adalah campuran aseton dan etanol dengan perbandingan 1:1. Secara organoleptis rekristal yang dihasilkan berupa serbuk halus berwarna kuning terang dan hablur. Sedangkan dispersi padat yang diperoleh berwarna putih kuning pucat, dengan bentuk serbuk licin seperti lilin, tidak berbau, dan agak higroskopis seperti yang ditunjukkan dalam Gambar 2.

Panjang Gelombang Maksimum dan Kurva baku Piroksikam

Pada penentuan panjang gelombang serapan maksimum piroksikam ditentukan dengan spektrofotometri UV-Vis dengan merekam spektra pada panjang gelombang 200-400 nm. Larutan standar piroksikam 0,1 $\mathrm{mg} / \mathrm{ml}$ yang dibuat mempunyai absorbansi maksimum pada panjang gelombang $340,80 \mathrm{~nm}$. Pembuatan kurva baku piroksikam dilakukan dengan mengambil larutan standar piroksikam $0,1 \mathrm{mg} / \mathrm{ml}$ dan mengencerkan menjadi 6 seri kadar larutan. Seri kadar yang dibuat yaitu $0,3 \mathrm{mg} / 100 \mathrm{ml}$, 0,5 mg/100 ml , 0,7 mg/100 ml, 0,9 mg/100
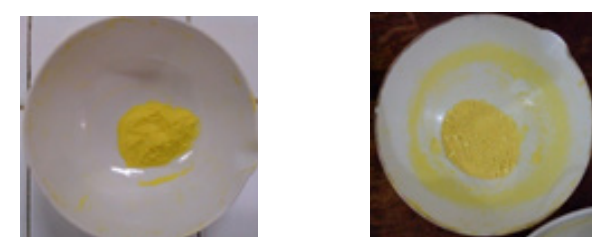

Gambar 2 Hasil pembentukan rekristal (kiri) dan dispersi padat (kanan) 


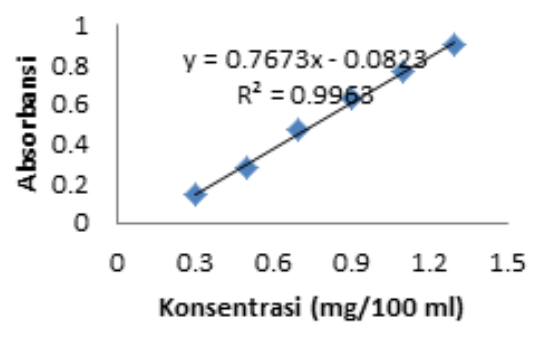

Gambar 3 Kurva Baku Piroksikam

$\mathrm{ml}, 1,1 \mathrm{mg} / 100 \mathrm{ml}, 1,3 \mathrm{mg} / 100 \mathrm{ml}$. Data kurva baku piroksikam tersaji pada Gambar 3. Diperoleh persamaan regresi linear piroksikam yaitu $\mathrm{y}=0,767 \mathrm{x}-0,082$ dengan $\mathrm{r}$ hitung 0,998 (r2=0,996) dan $\mathrm{r}$ tabel 0,811 (r hitung $>\mathrm{r}$ tabel).

\section{Uji Stabilitas Disolusi}

Profil disolusi dalam Gambar 4 menunjukkan jumlah obat yang terdisolusi tiap waktu pengambilan pada saat disolusi pada hari ke 0. Parameter disolusi dihitung dan hasil dianalisis dengan ANOVA satu jalan (SPSS for Windows) antar kelompok rekristal, dispersi padat, dan kontrol. Hasil analisis statistika menyatakan bahwa perbedaan antar kelompok yang didapat tidak bermakna $(\mathrm{p}>0,05)$. Hal ini menunjukkan bahwa pembentukan rekristal piroksikam dan dispersi padat piroksikamPEG 6000 (1:1), dan kontrol mempunyai nilai DE60, C45, dan t80 yang sama, artinya dispersi padat dan rekristalisasi tidak memperbaiki disolusi.

Uji stabilitas disolusi didahului dengan melakukan penyimpanan kapsul piroksikam dengan wadah yang tertutup rapat dan terlindung dari cahaya. Wadah yang tertutup rapat ini disimpan dalam suhu terjaga yaitu suhu ruangan. Secara kimia, piroksikam padat stabil dalam suhu ruang terkontrol 20o-25oC,18 sehingga jika terjadi penurunan kecepatan disolusi bukan disebabkan oleh penurunan potensi piroksikam dalam kapsul, tetapi karena perubahan fisik yang berpengaruh terhadap disolusi.

Kurva nilai parameter disolusi selama penyimpanan ditunjukkan dalam gambar 5 . Data profil disolusi berupa DE60, C45, dan t80 dari tiga kapsul yang disimpan di plot-kan terhadap waktu penyimpanan pada masingmasing replikasi dan didapatkan nilai slope. Harga negatif slope menunjukkan tingkat stabilitas dari suatu produk. Semakin negatif nilai slope pada kurva DE60 dan C45 terhadap waktu penyimpanan dan semakin positif pada t80 menunjukkan ketidakstabilan disolusi. Nilai slope yang diperoleh dirangkum dalam Tabel I.

Untuk mengetahui apakah perubahan nilai parameter disolusi yang terjadi selama penyimpanan itu benar-benar karena perubahan sifat fisika atau hanya kesalahan acak prosedur penelitian, maka dilakukan uji statistika one sample $\mathrm{t}$ test (SPSS) antara nilai slope (4 replikasi) dengan nilai 0 . Jika nilai slope berbeda bermakna

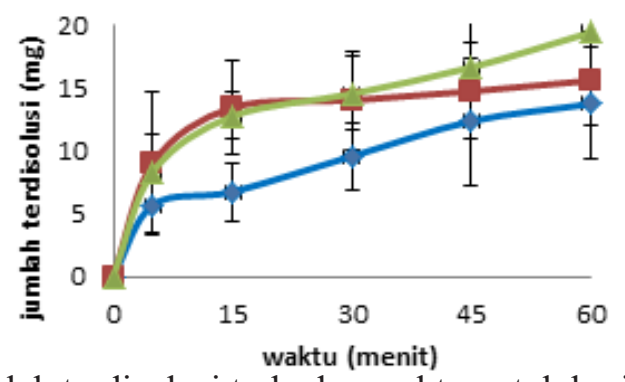

Gambar 4 Grafik rata-rata jumlah terdisolusi terhadap waktu untuk hari ke $0, \downarrow$ : rekristal, $\mathbf{~ : ~ d i s p e r s i ~}$ padat, $\boldsymbol{\Delta}$ : tanpa modifikasi 

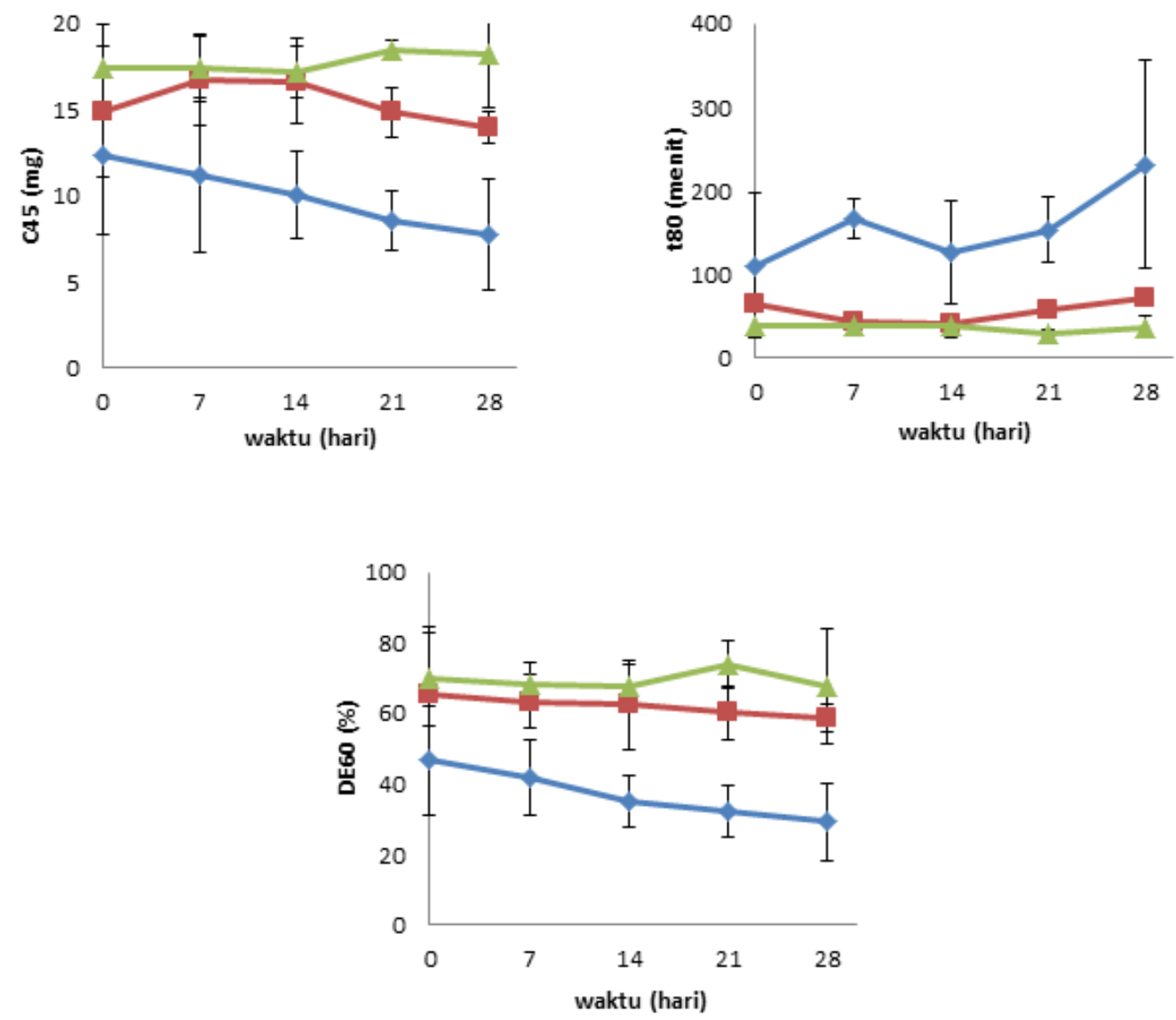

Gambar 5 Kurva nilai parameter disolusi selama 28 hari penyimpanan, keterangan symbol; $\bullet$ rekristal, 口 : dispersi padat, $\boldsymbol{\Delta}$ : tanpa modifikasi, $\mid$ : standard deviation dari 4 kali replikasi.

$(\mathrm{p}<0,05)$ dengan nilai 0 berarti memang ada perubahan karakter disolusi. Dalam Tabel 1 ditunjukkan dengan tanda *, yang berarti slope tersebut tidak sama dengan 0 .

Untuk hasil rekristalisasi nilai slope DE60 dan C45 versus waktu penyimpanan menunjukan nilai $\mathrm{p}<0,05$ hal ini menunjukkan bahwa rekristal piroksikam selama penyimpanan mengalami penurunan laju disolusi, sedangkan dispersi padat piroksikam-PEG 6000 dan kontrol piroksikam tanpa modifikasi mempunyai laju disolusi yang stabil selama penyimpanan.

\section{Pembahasan}

Beberapa penelitian menunjukkan bahwa pembentukan dispersi padat dapat meningkatan kelarutan maupun kelarutan intrinsik piroksikam. ${ }^{1,11}$ Sesuai dengan hukum Noyes-Whitney tentang disolusi, peningkatan kelarutan zat dapat meningkatkan kecepatan disolusinya, ${ }^{22}$ tetapi dalam penelitian ini tidak terjadi peningkatan disolusi. Hasil yang diperoleh dari penelitian ini juga berbeda dengan hasil penelitian Varma dkk maupun Das $\mathrm{dkk}^{17,23}$ di mana terjadi peningkatan disolusi piroksikam. Perbedaan ini kemungkinan terjadi karena perbedaan jenis solven dan banyaknya piroksikam yang diuji disolusinya. Pada penelitian Varma dkk jumlah piroksikam yang ditambahkan dalam $900 \mathrm{~mL}$ medium disolusi buffer phosphate $\mathrm{pH} 7$ adalah $100 \mathrm{mg}$. Pada penelitian ini jumlah piroksikam yang ditambahkan adalah $20 \mathrm{mg}$ (sesuai dengan dosis sekali pakai piroksikam) dengan medium $500 \mathrm{~mL}$ dapar $\mathrm{HCl} \mathrm{pH}$ 1,2 (sesuai dengan $\mathrm{pH}$ cairan lambung), $\mathrm{pH}$ medium ini sama dengan medium yang disarankan oleh monograf USP. ${ }^{19}$ Penelitian dari Das 
Tabel 1 Hasil rata-rata slope \pm SD parameter disolusi sebagai fungsi lama penyimpanan, tanda * menunjukkan bahwa nilai tersebut berbeda bermakna dengan 0 pada uji one sample t-test $(\mathrm{p}<0,05)$

\begin{tabular}{cclc}
\hline Parameter & Rekristalisasi & Dispersi Padat & Kontrol \\
\hline $\mathrm{DE}_{60}(\% /$ hari $)$ & $-0,636 \pm 0,244^{*}$ & $-0,243 \pm 0,434$ & $0,025 \pm 0,800$ \\
$\mathrm{C}_{45}(\mathrm{mg} /$ hari $)$ & $-0,170 \pm 0,091^{*}$ & $-0.053 \pm 0,068$ & $0,038 \pm 0,141$ \\
$\mathrm{t}_{80}$ (menit/hari) & $3,232 \pm 2,365$ & $0,379 \pm 1,387$ & $-0,232 \pm 0,796$ \\
\hline
\end{tabular}

dkk dengan medium $\mathrm{HCl}$ dengan $\mathrm{pH}$ 1,2 juga menunjukkan peningkatan kecepatan disolusi, sehingga faktor $\mathrm{pH}$ medium tidak mendominasi. Faktor jumlah obat yang ditambahkan lebih menentukan terhadap hasil uji disolusi dalam percobaan ini. Dengan jumlah piroksikam yang lebih sedikit dalam penelitian ini, maka problema disolusi piroksikam tanpa modifikasi kemungkinan tidak terjadi.

Penelitian yang dilakukan Shohin $\mathrm{dkk}^{24}$ menunjukkan bahwa kapsul piroksikam generik dari berbagai dunia dapat melarut dalam medium disolusi dapar $\mathrm{HCl} \mathrm{pH} \mathrm{1,2}$ mencapai $85 \%$ dalam waktu 30 menit. Jadi jika dibandingkan dari hasil penelitian ini modifikasi dengan rekristalisasi dan pembentukan dispersi padat piroksikam belum memenuhi pencapaian disolusi produk dipasaran. Hal ini terjadi kemungkinan karena sebelum dimasukkan dalam kapsul, serbuk piroksikam tidak diayak terlebih dahulu, sehingga memiliki ukuran yang lebih besar dan luas permukaan efektif yang lebih kecil. Tetapi jika dibandingkan dengan batas toleransi dari USP, maka kristal piroksikam tanpa modifikasi dan dispersi padat piroksikam memenuhi persyaratan, yaitu $\mathrm{C} 45$ lebih dari $75 \% .{ }^{19}$

Obat dalam bentuk kristal secara umum lebih keras, kaku (rigid) dan secara termodinamik lebih stabil daripada bentuk amorf, kondisi ini menyebabkan obat bentuk amorf lebih mudah terdisolusi daripada bentuk kristal. ${ }^{25}$ Tetapi obat padatan amorf dapat berubah menjadi padatan kristal selama penyimpanan, di mana perubahannya tidak selalu melewati semua tahapan metastabil, tetapi dapat melompat menjadi bentuk yang tidak stabil sehingga kelarutannya menjadi rendah dalam medium. ${ }^{26}$ Kelembapan mungkin dapat mendorong pembentukan kristal dari farmaseutikal amorf. Fase pembentukan kristal obat ke bentuk yang lebih stabil dari bentuk kristal metastabil selama proses penyimpanan merupakan hambatan utama karena dapat menyebabkan kelarutan dan disolusi akan menurun. ${ }^{27}$

Perubahan bentuk kristal selama penyimpanan dipengaruhi oleh lingkungan tempat sediaan obat dan tidak dapat dilihat secara organoleptik, maupun dengan pengukuran kandungan zat aktif, tetapi umumnya menyebabkan perubahan dalam pelepasannya, ${ }^{28}$ sehingga dengan dasar ini penyimpanan jangka panjang padatan amorf atau padatan kristal metastabil hasil rekristalisasi dapat terjadi pembentukan kristal yang berbeda dari bentuk kristal awal sehingga membuat piroksikam menjadi tidak stabil selama penyimpanan.

Pada dispersi padat piroksikam-PEG 6000 nilai negatif slope DE60 berbeda tidak bermakna dibandingkan $0(\mathrm{p}>0,05)$, artinya disolusi dispersi padat stabil selama penyimpanan. Pada dispersi padat, perbaikan disolusi tidak hanya karena pembentukan padatan amorf atau polimorf metastabil saja, tetapi bisa juga disebabkan oleh terbentuknya senyawa kompleks yang mudah larut, sehingga perbaikan disolusi dapat bertahan lebih lama dari pada hasil rekristalisasi. Selain itu, adanya pembawa dapat menstabilkan padatan amorf yang terbentuk, sehingga transformasi dari padatan amorf menjadi padatan kristal dapat dihambat. ${ }^{9}$ 


\section{Kesimpulan}

Pembentukan dispersi padat piroksikam-PEG 6000 (1:1) dan rekristal piroksikam dengan metode pelarut dengan pelarut aseton-etanol $(1: 1)$ tidak dapat memperbaiki disolusi kapsul piroksikam 20 mg. Selama penyimpanan 1 bulan disolusi kapsul dispersi padat piroksikam tidak mengalami penurunan, sedangkan kapsul piroksikam hasil rekristalisasi disolusinya semakin menurun.

\section{Ucapan Terimakasih}

Terimakasih kepada Lembaga Penelitian dan Pengembangan Universitas Ahmad Dahlan yang telah mendanai penelitian ini melalui hibah penelitian mandiri.

\section{Daftar Pustaka}

1. Sanka K, Munjulury VS, Mohd AB, Diwan PV. Enhancement of solubility, dissolution release profile and reduction in ulcerogenicity of piroxicam by inclusion complex with skimmed milk. Drug Deliv. 2014 Nov;21(7):560-70.

2. Dixit M, Kulkarni PK. Lyophilization monophase solution technique for improvement of the solubility and dissolution of piroxicam. Res Pharm Sci. 2012 Jan;7(1):13-21.

3. Savjani KT, Gajjar AK, Savjani JK. Drug Solubility: Importance and Enhancement Techniques. ISRN Pharm. 2012 Jul 5;2012:1-10.

4. Shah TJ, Amin AF, Parikh JR, Parikh RH. Process optimization and characterization of poloxamer solid dispersions of a poorly water-soluble drug. AAPS PharmSciTech. 2007 Jun;8(2):E18-24.

5. Dixit M, Kini AG, Kulkarni PK. Preparation and characterization of microparticles of piroxicam by spray drying and spray chilling methods. Res Pharm Sci. 2010;5(2):89-97.

6. Kumpugdee-Vollrath M, Ibold Y. Increasing Solubility of Poorly Water Soluble Drug Resveratrol by Surfactants and Cyclodextrins. Adv Mater Res.
2011 Dec;418-420:2231-4.

7. Huang Y, Dai W-G. Fundamental aspects of solid dispersion technology for poorly soluble drugs. Acta Pharm Sin B. 2014 Feb;4(1):18-25.

8. Bouchal F, Skiba M, Chaffai N, Hallouard F, Fatmi S, Lahiani-Skiba M. Fast dissolving cyclodextrin complex of piroxicam in solid dispersion part I: influence of $\beta-C D$ and $\mathrm{HP} \beta-\mathrm{CD}$ on the dissolution rate of piroxicam. Int $\mathrm{J}$ Pharm. 2015 Jan 30;478(2):625-32.

9. Valizadeh $H$, Zakeri-Milani $P$, Barzegar-Jalali M, Mohammadi G, Danesh-Bahreini M-A, Adibkia K, et al. Preparation and characterization of solid dispersions of piroxicam with hydrophilic carriers. Drug Dev Ind Pharm. 2007 Jan;33(1):45-56.

10. Swidan S. Design, Formulation and Evaluation of Piroxicam Capsules Prepared by Solid Dispersion Technique. Br J Pharm Res. 2013 Jan 10;3(1):108-34.

11. Budiarto S, Binarjo A. Enhancement of Piroxicam Intrinsic Dissolution Rate via Solid Dispersion using Beta Cyclodextrin. In: Proceeding of International Conference On Drug Development Of Natural Resources. Faculty of Pharmacy, Ahmad dahlan University, Yogyakarta; 2012. p. 373-

12. Verma MM, Kumar MT, Balasubramaniam J, Pandit JK. Dissolution, bioavailability and ulcerogenic studies on piroxicamnicotinamide solid dispersion formulations. Boll Chim Farm. 2003 Apr;142(3):119-24.

13. Mishra DN, Vijaya Kumar SG. Investigations on analgesic, antiinflammatory and ulcerogenic potential of meloxicam solid dispersion prepared with skimmed milk. Yakugaku Zasshi. $2006 \mathrm{Jul} ; 126(7): 495-8$.

14. Vijaya Kumar SG, Mishra DN. Analgesic, antiinflammatory, and ulcerogenic studies of meloxicam solid dispersion prepared with polyethylene 
glycol 6000. Methods Find Exp Clin Pharmacol. 2006 Sep;28(7):419-22.

15. Lee EH. A practical guide to pharmaceutical polymorph screening \& selection. Asian J Pharm Sci. 2014 Aug;9(4):163-75.

16. Murthy KS, Ghebre-Sellassie I. Current perspectives on the dissolution stability of solid oral dosage forms. J Pharm Sci. 1993 Feb;82(2):113-26.

17. Varma V, Sowmya C, Tabasum S. Formulation and Evaluation of Piroxicam Solid Dispersion with Suitable Carrier. Res J Pharm Biol Chem Sci. 2012;3(3):929-41.

18. Binarjo A. Stabilitas fisika dan kimia rekristal dan dispersi padat piroksikamPEG 6000. Pharmaciana. 2015 May 31;5(1):61-9.

19. USP Monographs: Piroxicam Capsules [Internet]. [cited 2016Aug 31]. Available from: http://www.pharmacopeia.cn/ v29240/usp29nf24s0_m65723.html

20. Khan KA. The concept of dissolution efficiency. J Pharm Pharmacol. 1975 Jan;27(1):48-9.

21. Wagner J. Biopharmaceutical and Relevant Pharmacokinetic. Carson: Drug Inteligence Publication; 1971.

22. Dokoumetzidis A, Papadopoulou V, Macheras P. Analysis of dissolution data using modified versions of Noyes-Whitney equation and the Weibull function. Pharm Res. 2006
Feb;23(2):256-61.

23. Das IJ, Samal HB, Dey S. Enhancement of Dissolution Rate of Piroxicam Using Solid Dispersions With PEG-6000 and Eudragit RL-100. J Pharm Res. 2011;4(5):1473-80.

24. Shohin IE, Kulinich JI, Ramenskaya GV, Abrahamsson B, Kopp S, Langguth $\mathrm{P}$, et al. Biowaiver monographs for immediate release solid oral dosage forms: piroxicam. J Pharm Sci. 2014 Feb;103(2):367-77.

25. Shargel L, Yu B. A, Wu-Pong S. Biopharmaceutic Considerations in Drug Product Design and in Vitro Drug Product Performance. In: Applied Biopharmaceutics and Pharmacokinetics. 6th ed. New York: McGraw-Hill; 2012. p. 361-89.

26. Javadzadeh Y, Hamedeyazdan S, Asnaashari S. Recrystallization of Drugs: Significance on Pharmaceutical Processing. In: Processing. Tehran: Biotechnology Research Center, Faculty of Pharmacy Tabriz University of Medical Sciences; 2013. p. 425-48.

27. Brittain HG. Theory and Principles of Polymorphic Systems. In: Polymorphisme in Pharmaceutical Solid. 2nd ed. New York: Informa Healthcare; 2009. p. 1-24.

28. Ansel HC. Pengantar Bentuk Sediaan. 4th ed. Jakarta: UI Press; 2005. 